\title{
Structural basis for ligand and innate immunity factor uptake by the trypanosome haptoglobin-haemoglobin receptor
}

\author{
Harriet Lane-Serff', Paula MacGregor², Edward D Lowe', Mark Carrington²*, \\ Matthew K Higgins ${ }^{1 *}$
}

1Department of Biochemistry, University of Oxford, Oxford, United Kingdom; ${ }^{2}$ Department of Biochemistry, University of Cambridge, Cambridge, United Kingdom

\begin{abstract}
The haptoglobin-haemoglobin receptor $(\mathrm{HpHbR})$ of African trypanosomes allows acquisition of haem and provides an uptake route for trypanolytic factor-1, a mediator of innate immunity against trypanosome infection. In this study, we report the structure of Trypanosoma brucei $\mathrm{HpHbR}$ in complex with human haptoglobin-haemoglobin $(\mathrm{HpHb})$, revealing an elongated ligand-binding site that extends along its membrane distal half. This contacts haptoglobin and the $\beta$-subunit of haemoglobin, showing how the receptor selectively binds $\mathrm{HpHb}$ over individual components. Lateral mobility of the glycosylphosphatidylinositol-anchored $\mathrm{HpHbR}$, and a $\sim 50^{\circ}$ kink in the receptor, allows two receptors to simultaneously bind one $\mathrm{HpHb}$ dimer. Indeed, trypanosomes take up dimeric $\mathrm{HpHb}$ at significantly lower concentrations than monomeric $\mathrm{HpHb}$, due to increased ligand avidity that comes from bivalent binding. The structure therefore reveals the molecular basis for ligand and innate immunity factor uptake by trypanosomes and identifies adaptations that allow efficient ligand uptake in the context of the complex trypanosome cell surface.
\end{abstract}

DOI: 10.7554/eLife.05553.001

*For correspondence: mc115@ cam.ac.uk (MC); matthew. higgins@bioch.ox.ac.uk (MKH)

Competing interests: The authors declare that no competing interests exist.

Funding: See page 15

Received: 11 November 2014 Accepted: 12 December 2014 Published: 12 December 2014

Reviewing editor: Volker Dötsch, Goethe University, Germany

(c) Copyright Lane-Serff et al. This article is distributed under the terms of the Creative Commons Attribution License, which permits unrestricted use and redistribution provided that the original author and source are credited.

\section{Introduction}

African Animal Trypanosomiasis is one of the major constraints on the productivity of pastoralists in sub-Saharan Africa and can be caused by infection by a range of trypanosome species (Shaw, 2004), while infections of humans are caused by only two subspecies of Trypanosoma brucei (Laveran, 1902; Pays and Vanhollebeke, 2009). The disease is persistent as the host immune system is usually unable to clear the infection. This is due to the trypanosome having evolved a population survival strategy based on autoregulation of parasitaemia and antigenic variation (MacGregor et al., 2011; Horn, 2014). The trypanosomes also internalize and degrade surface bound immunoglobulin (Pal et al., 2003; Engstler et al., 2007), increasing the survival of an individual cell and thereby increasing the likelihood of transmission. Both of these strategies require a densely packed cell surface coat of variant surface glycoprotein (VSG) that acts as a barrier, preventing access of host immunoglobulins to the plasma membrane (Schwede and Carrington, 2010). This coat also undergoes antigenic variation through expression of a single VSG gene from a genomic repertoire of hundreds (Horn, 2014).

Although the VSG coat restricts immunoglobulin access, it must be permissive for receptor-mediated binding and uptake of macromolecular ligands. T. brucei, and the closely related T. congolense, have receptors for both transferrin (TfR) for iron (Steverding et al., 1994; Schell et al., 1991; Jackson et al., 2013) and haptoglobin-haemoglobin (HpHbR) for haem (Vanhollebeke et alı, 2008; Higgins et al., 2013). These are held on the external face of the plasma membrane by covalent attachment of the C-terminal carboxyl group to a glycosylphosphatidyl inositol to form a GPI-anchor. All have free movement in the lateral plane of the membrane, although the receptors are concentrated in the flagellar 
eLife digest African Trypanosomes are a group of single-celled parasites that are a major concern for livestock farmers in sub-Saharan Africa. They are carried by the tsetse fly and can cause disease in domestic livestock that diminishes productivity through reduced growth, and may ultimately lead to death. The parasites are coated in a dense layer of protein that help them evade the host's immune system by preventing immune cells from identifying them.

Humans have evolved immunity to many trypanosome species by exploiting a weakness in their lifestyle. Trypanosomes need to get haem-a molecule found in the protein haemoglobin-from their host to survive. In blood plasma, haemoglobin is found associated with a carrier protein called haptoglobin. To acquire haem, the parasites have a protein called $\mathrm{HpHbR}$ that binds to these haptoglobin-haemoglobin 'complexes'. However, in humans there are two complexes of proteins called TLFs that contain haemoglobin and a protein related to haptoglobin. The TLFs are also able to bind to $\mathrm{HpHbR}$ and are taken into the parasite. Once inside, TLFs cause internal compartments called lysosomes to swell, which leads to the death of the trypanosome.

Two subspecies of Trypanosoma brucei are the only trypanosomes that infect humans as they can overcome the TLF1 defense. However, the details of how TLFs cause cell death at the molecular level are not clear.

Lane-Serff et al. used a technique called x-ray crystallography to generate 3-D images of the $\mathrm{HpHbR}$ protein from $\mathrm{T}$. brucei bound to the haptoglobin-haemoglobin complexes. These images show that $\mathrm{HpHbR}$ is elongated so that it only binds to haemoglobin and haptoglobin when they are together as a complex.

The images also reveal that the shape of $\mathrm{HpHbR}$ enables it to hold apart the proteins in the protective layer that coats the trypanosome. This allows the haptoglobin-haemoglobin complex to bind to $\mathrm{HpHbR}$, but in humans also makes $\mathrm{HpHbR}$ more likely to bind to TLF1. These findings may help to guide future efforts to protect humans and livestock from the diseases caused by trypanosomes. DOI: 10.7554/eLife.05553.002

pocket, an invagination of the plasma membrane at the base of the flagellum and the site of all endocytosis (Mussmann et al., 2004; Vanhollebeke et al., 2008).

Humans, together with a few other primates, display innate immunity to most trypanosome species (Laveran, 1902) through the action of trypanolytic factors-1 and -2 (TLF1 and TLF2) (Hager et alo, 1994; Raper et alo, 1996, 1999). Although containing different scaffold components, these factors both include apolipoprotein L1 (ApoL1) together with complexes of haemoglobin bound to haptoglobinrelated protein ( $\mathrm{HprHb}$ ) (Vanhamme et al., 2003; Pérez-Morga et al., 2005). TLF1 enters trypanosomes via receptor-mediated endocytosis, through binding of the $\mathrm{HprHb}$ component to $\mathrm{HpHbR}$ (Drain et al., 2001; Widener et al., 2007; Vanhollebeke et al., 2008). This delivers ApoL1 to the endosome where it causes lysosomal swelling and cell death (Pérez-Morga et al., 2005). In contrast, the uptake route for TLF2 is unclear as, unlike TLF1, it is able to kill HpHbR null mutants (Capewell et al., 2013; Uzureau et al., 2013).

Just two subspecies of T. brucei (T. b. rhodesiense and T. b. gambiense) have evolved counter measures to the trypanolytic factors, allowing them to cause Human African Trypanosomiasis (Pays et al., 2014). In the case of human-infective group $1 \mathrm{~T}$. b. gambiense, a unique point polymorphism is found in HpHbR (Symula et al., 2012) that reduces the monovalent affinity for ligand by 20 -fold (Higgins et al., 2013). This contributes to resistance to TLF1, illustrating the importance of HpHbR.

Haptoglobin-haemoglobin is an elongated 'dumbell-shaped' complex consisting of a dimer of haptoglobin molecules, each joined to an $\alpha \beta$ haemoglobin dimer (Andersen et al., 2012). Trypanosomes take up this $\mathrm{HpHb}$ complex but not the individual components (Vanhollebeke et al., 2008). The structure of the T. congolense HpHbR is an elongated three-helical bundle with a small membrane distal head (Higgins et alo, 2013). Residues involved in $\mathrm{HpHb}$ binding are part of a small conserved patch $\sim 25 \AA$ below the tip of the receptor, but details of ligand binding and uptake were not characterized.

Here, we present the structure of $T$. brucei HpHbR. We show that the receptor adopts a similar architecture to its $T$. congolense homologue, but with a $\sim 50^{\circ}$ kink a third of the way along from the membrane proximal end. We also present the structure of $\mathrm{TbHpHbR}$ in complex with $\mathrm{HpHb}$, revealing the molecular basis for ligand binding and selectivity. Finally, we show that the kink allows two independent membrane 
attached receptors to interact with a single dimeric $\mathrm{HpHb}$ molecule and confirm using cell uptake experiments that this causes dimeric ligand to be taken up with greater efficiency than monomeric ligand. This reveals the molecular basis for the uptake of $\mathrm{HpHb}$ and trypanolytic factor- 1 and identifies adaptations in the trypanosome receptor that allow efficient ligand uptake in the context of the tightly packed VSG coat.

\section{Results}

\section{TbHpHbR binds to the HpSP domain:Hb head structure}

To provide detailed molecular knowledge of the mechanism of uptake of haptoglobin-haemoglobin and trypanolytic factor-1 (TLF1), we aimed to determine the structure of T. brucei HpHbR (TbHpHbR) alone and bound to a human haptoglobin-haemoglobin complex.

$\mathrm{TbHpHbR}$ is longer than its homologue from $T$. congolense due to the presence of an additional C-terminal membrane-proximal domain. We therefore used the previously determined structure of T. congolense HpHbR (Higgins et al., 2013) to design a construct containing the corresponding region of TbHpHbR (residues 36-299). This region of the protein is identical in the human infective T. b. rhodesiense.

Haptoglobin-haemoglobin consists of a dimer of haptoglobin chains, each interacting with an $\alpha \beta$ dimer of haemoglobin, and adopts a dimeric 'dumbell-shaped' architecture (Andersen et al., 2012). At each end, a serine protease (HpSP) domain of haptoglobin forms a stable complex with a haemoglobin dimer. Dimerisation occurs through an interface formed by the CCP domains of haptoglobin, linking together these HpSPHb 'heads'.

Previous studies have shown that $\mathrm{TbHpHbR}$ interacts with the $\mathrm{HpHb}$ complex but not with either haptoglobin or haemoglobin alone (Vanhollebeke et al., 2008), suggesting that that the receptor most likely binds to the heads of $\mathrm{HpHb}$, where its two constituent components come together. We therefore designed a human haptoglobin construct containing just the SP domain (residues 148-406). This was expressed in baculovirus-infected insect cells and was combined with haemoglobin extracted from human blood to assemble $\mathrm{HpSPHb}$ complexes. We used surface plasmon resonance to determine the affinity of these $\mathrm{HpSPHb}$ complexes for TbHpHbR, and showed binding with an affinity of $0.7 \mu \mathrm{M}$ (Figure 1-figure supplement 1), similar to the $1 \mu \mathrm{M}$ affinity observed for intact human $\mathrm{HpHb}$ (Higgins et al., 2013).

Proteolytic cleavage of haptoglobin normally occurs in the endoplasmic reticulum after residue R102 but this cleavage event did not occur in the insect cell expressed HpSP domain. However, this did not affect the affinity for TbHpHbR. The shortened TbHpHbR construct and the HpSPHb complex therefore interact together with the same affinity as the full-length components, providing reagents for structural determination. These findings also confirm that $\mathrm{TbHpHbR}$ binds to the 'head' structure of dimeric $\mathrm{HpHb}$, raising the possibility of two receptors simultaneously interacting with one $\mathrm{HpHb}$ complex.

\section{Determination of the structure of TbHpHbR alone and in complex with HpSPHb}

To investigate the molecular basis for $\mathrm{HpHb}$ binding by $\mathrm{TbHpHbR}$, crystallisation plates were set up for $\mathrm{HpSPHb}, \mathrm{TbHpHbR}$ and a complex containing TbHpHbR bound to HpSPHb. Crystals of HpSPHb diffracted to $2.05 \AA$ and were of space group P3,21 with one complex in the asymmetric unit. Crystals of TbHpHbR diffracted to $1.85 \AA$ resolution and were of space group P2 1 with two molecules in the asymmetric unit. Crystals of the TbHpHbR:HpSPHb complex were of space group $\mathrm{C} 2$ and diffracted to 3.1 A resolution with a single complex in the asymmetric unit (Table 1).

The structure of human $\mathrm{HpSPHb}$ was determined using molecular replacement with the equivalent region of porcine $\mathrm{HpHb}$ (pdb: $4 \mathrm{~F} 4 \mathrm{O}$ ) as a search model. The structure of the TbHpHbR:HpSPHb complex was then determined through molecular replacement using $\mathrm{HpSPHb}$ as a search model, allowing a poly-alanine model of $\mathrm{TbHpHbR}$ to be built. This model was then used as a molecular replacement search model to determine the structure of $\mathrm{TbHpHbR}$ using higher-resolution data obtained from crystals of the receptor alone. Both structures were then completed using iterative cycles of model building and refinement (Table 2).

\section{The structure of the $T$. brucei haptoglobin-haemoglobin receptor}

Like $T$. congolense $\mathrm{HpHbR}$, the $T$. brucei receptor is elongated, consisting primarily of a three-helical bundle (Figure 1): helix I (red; residues 42-110), helix II (orange; residues 116-182), and helix V (dark blue; residues 224-296) with a total length of $118 \AA$. At the membrane distal end, the receptor widens to form a compact head structure that includes the $\mathrm{N}$-terminus and a 42-residue loop containing two 
Table 1. Crystallographic data collection statistics

\begin{tabular}{|c|c|c|c|}
\hline & HpSPHb & Tbb HpHbR & TbbHpHbR:HpSPHb \\
\hline Beamline & Diamond I04-1 & Diamond I03 & Diamond I03 \\
\hline Space Group & $\mathrm{p} 3,21$ & $p 2_{1}$ & c2 \\
\hline Cell dimensions $(\AA)$ & $a=b=96.6, c=132.77$ & $\begin{array}{l}a=27.90, b=47.79 \\
c=203.38, \beta=92.79\end{array}$ & $\begin{array}{l}a=223.4, b=56.59 \\
c=65.29, \beta=92.99\end{array}$ \\
\hline Resolution ( $(\AA)$ & 2.05 & 1.85 & 3.1 \\
\hline Wavelength $(\AA)$ & 0.916 & 0.9763 & 0.9750 \\
\hline $\mathrm{R}_{\mathrm{PIM}}(\%)$ & $8.1(37.4)$ & $4.5(42.9)$ & $6.3(72.6)$ \\
\hline $1 / \sigma(I)$ & $8.7(2.3)$ & $10.2(2.0)$ & $9.8(1.6)$ \\
\hline Completeness (\%) & $99.8(100)$ & $97.4(96.5)$ & $96.9(97.1)$ \\
\hline Multiplicity & $9.6(10.2)$ & $3.1(3.1)$ & $3.2(3.3)$ \\
\hline
\end{tabular}

DOI: 10.7554/eLife.05553.003

further helices, helix III (yellow: residues 186-196) and helix IV (green: residues 207-218). The upper part of the structure is extremely similar to that from $T$. congolense, with the membrane distal halves of the two receptors aligning with a root mean square deviation of $1.1 \AA$ (Figure 1-figure supplement 2).

The most dramatic difference between the T. brucei and T. congolense receptors is a $\sim 50^{\circ}$ kink in $\mathrm{TbHpHbR}$, located approximately one-third of the way along the receptor from the membrane proximal end. Each of the three helices is affected, with the backbone carbonyl groups of Asp88, Ala89, Glu123, Asn124, Asp270 and Ala271 no longer forming hydrogen bonds. This kink is not caused by flexibility, but is a rigid feature of the receptor, as it adopts the same confirmation in crystals of receptor alone, and in crystals of its complex with HpSPHb (Figure 2A), and is also observed in molecular envelopes derived from small angle x-ray scattering (Figure 1, Table 3). Instead it is caused by changes in the pattern of hydrophobic and hydrophilic residues around the kink site in each of the three helices. The three long helices of the T. congolense receptor are characterised by an alternating pattern of hydrophobic and hydrophilic residues, leading to continuous hydrophobic strips along the length of each helix that pack in the core of the helical bundle, stabilising its fold. In the T. brucei receptor, this pattern is disturbed at each kink site, breaking the organisation of the helix and leading to an alteration in the surface that displays the hydrophobic patch (Figure 1C). This stabilises the kink and makes it a rigid feature of the receptor structure.

\section{The structure of TbHpHbR in complex with haptoglobin-haemoglobin}

The structure of the TbHpHbR:HpSPHb complex reveals an unexpected binding mode in which the ligand-binding surface extends along more than half of the length of the receptor (Figure 2,

Table 2. X-ray refinement statistics

\begin{tabular}{llll} 
Complex & HpSPHb & Tbb HpHbR & TbbHpHbR:HpSPHb \\
\hline Resolution ( $\AA$ ) & 2.05 & 1.85 & 3.1 \\
\hline No. reflections & 43,170 & 44,685 & 17,302 \\
\hline$R_{\text {work }} / R_{\text {free }}(\%)$ & $18.0 / 22.4$ & $19.84 / 23.95$ & $19.5 / 21.7$ \\
\hline No. of protein residues in model & 544 & 523 & 782 \\
\hline rmsd bond lengths $(\AA)$ & 0.020 & 0.017 & 0.012 \\
\hline rmsd bond angles $\left(^{\circ}\right)$ & 2.0 & 1.6 & 1.5 \\
\hline Ramachandran plot & & & \\
\hline Allowed region & $89.0 \%$ & $98.8 \%$ & $7.5 \%$ \\
\hline Additional allowed region & $11 \%$ & $1.2 \%$ & $0 \%$ \\
\hline Generously allowed region & $0 \%$ & $0 \%$ & $0 \%$ \\
\hline Disallowed region & $0 \%$ & $0 \%$ & \\
\hline
\end{tabular}

DOI: 10.7554/eLife.05553.004 


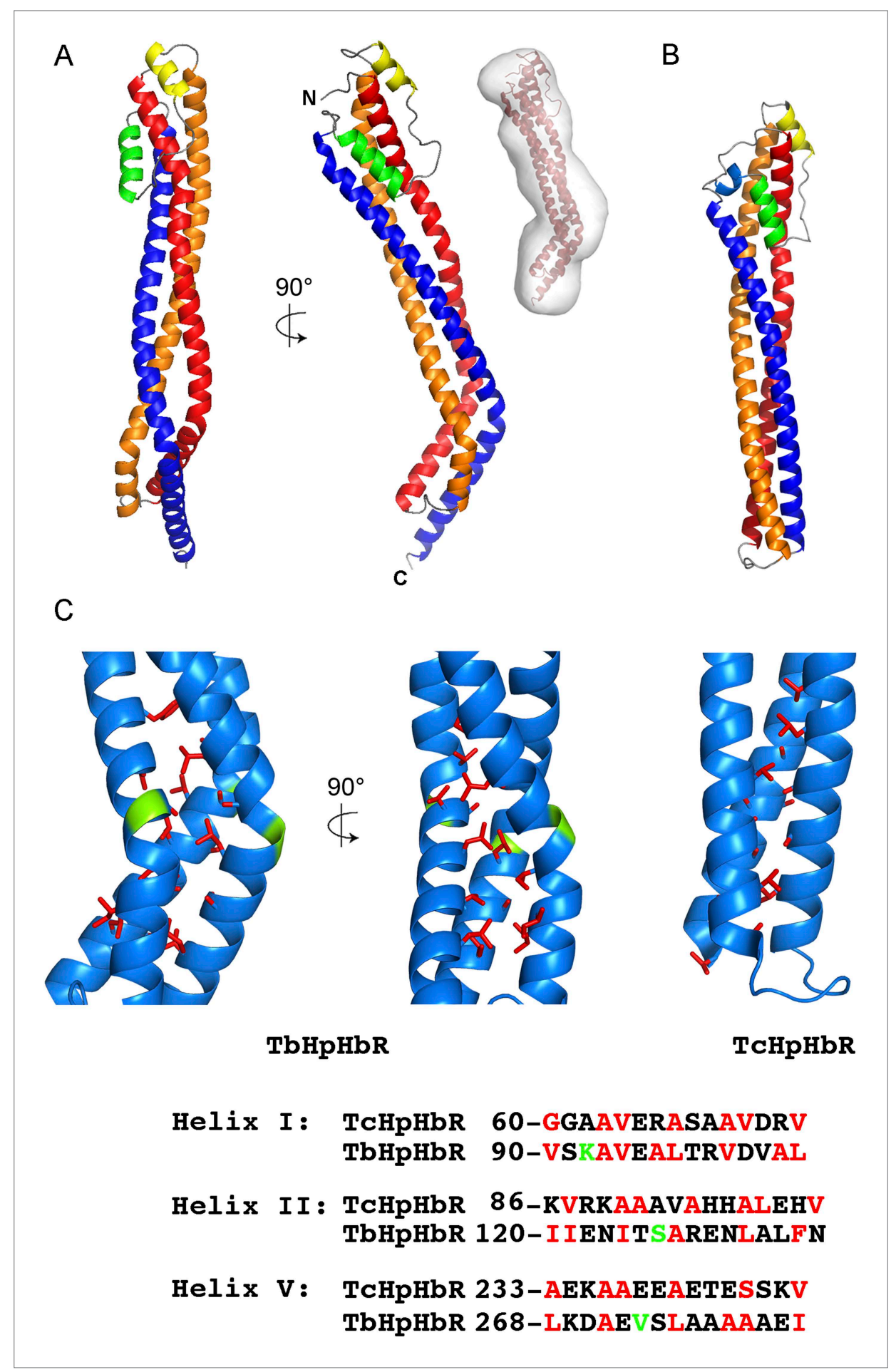

Figure 1. The structure of the T. brucei haptoglobin-haemoglobin receptor. (A) The structure of the T. brucei haptoglobin-haemoglobin receptor, with helix I (red), helix II (orange) and helix V (blue). These three helices form an elongated bundle with a $\sim 50^{\circ}$ kink towards the membrane proximal C-terminal end. The inset shows a molecular envelope derived from small angle $x$-ray scattering. (B) The structure of the T. congolense haptoglobin-haemoglobin receptor (Higgins et al., 2013) for comparison. (C) A change in the pattern of hydrophobic residues results in a rigid kink in the three helical bundle of the TbHpHbR. Corresponding regions of the structures of TbHpHbR and $\mathrm{TcHpHbR}$ are shown with side chains of the hydrophobic residues that pack in the core of the bundle coloured Figure 1. Continued on next page 
Figure 1. Continued

red and residues at the kink sites in $\mathrm{TbHpHbR}$ coloured green. Also shown are sequence alignments of $\mathrm{TbHpHbR}$ and $\mathrm{TCHpHbR}$ for these regions of each helix, coloured in the same way.

DOI: 10.7554/eLife.05553.005

The following figure supplements are available for figure 1:

Figure supplement 1. Surface plasmon resonance analysis of the binding of $\mathrm{HpSPHb}$ to TbHpHbR. DOI: 10.7554/eLife.05553.006

Figure supplement 2. Alignment of the TbHpHbR and $\mathrm{TcHpHbR}$ structures. DOI: 10.7554/eLife.05553.007

Figure 2-figure supplement 1). Residues previously identified as playing a role in $\mathrm{HpHb}$ binding in TcHpHbR, such as S59 (Higgins et al., 2013), lie 35 ^ from the membrane distal tip of the receptor and directly contact haemoglobin. However, this is the upper part of the binding site, with residues from haptoglobin interacting as far as $70 \AA$ from the membrane distal tip. This arrangement is confirmed by small angle x-ray scattering, with complexes of HpSPHb bound to either T. brucei or T. congolense receptors showing a similar architecture to that observed in the crystal (Figure 2figure supplement 2, Table 3).

The haptoglobin-haemoglobin complex covers a total area of $\sim 1250 \AA^{2}$ of the receptor and can be divided into two distinct regions (Figure 2B). The membrane distal part, $\left(\sim 745 \AA^{2}\right)$ contacts the $\beta$-subunit of the haemoglobin dimer with no contacts between the receptor and the haemoglobin a-subunit. The membrane proximal region $\left(\sim 505 \AA^{2}\right)$ forms a binding surface for haptoglobin. The involvement of both haemoglobin and haptoglobin in binding explains why the receptor binds $\mathrm{HpHb}$ but not haptoglobin alone. Modelling suggests that the lack of haemoglobin binding is due to steric clashes of the receptor with the second $\alpha \beta$ dimer of haemoglobin when the $\beta$-subunit of a haemoglobin tetramer is docked onto the receptor with the binding mode observed in the TbHpHbR:HpSPHb complex (Figure 2-figure supplement 3). Therefore, the conformation of the receptor and the presence of two distinct binding sites allow the receptor to specifically select $\mathrm{HpHb}$ over its two constitutive components.

The haemoglobin $\beta$-subunit makes a number of direct interactions, mostly hydrogen bonds, with the receptor (Figure 2C, Table 4). Side chains from helix I of the receptor make the majority of these contacts, with additional interactions from helix II and the loop that links helices III and IV. These features lie along a groove on haemoglobin that is formed by helices $C$ and $F$ of the $\beta$-subunit. The haem group also makes direct contacts with the receptor, with the propionate chains contacting residues K56, S59, K164, R199 and Y200 of the receptor. These interactions, mediated by haem, form $\sim 140 \AA^{2}$ of the $\sim 745 \AA^{2}$ total contact area of $\mathrm{Hb}$.

The haptoglobin subunit also interacts with helix I of the receptor, through a predominantly hydrophobic contact, mediated by three loops that emerge from the C-terminal $\beta$-sheet of haptoglobin (Figure 2B, Table 4). The structure of human haptoglobin from this complex aligns with that from porcine $\mathrm{Hp}$ with a root mean square deviation of just $0.5 \AA$ and reveals no significant structural change on receptor binding (Figure 2-figure supplement 4). The alignment also confirms that the natural cleavage of $\mathrm{Hp}$ does not affect $\mathrm{TbHpHbR}$ binding, as residues in the loop that contains the cleavage site are not close to the receptor.

Rather than haptoglobin, trypanolytic factor-1 (TLF1) contains haptoglobin-related protein (Hpr) and binding of $\mathrm{HprHb}$ complex to TbHpHbR results in TLF1 uptake. The HprSP domain contains a total of sixteen amino acid substitutions when compared with the HpSP domain. Mapping these onto the structure shows that none of these differences lie in residues that contact the receptor (Figure 3A). Indeed $\mathrm{HprSPHb}$ complexes, prepared using the same protocols as $\mathrm{HpSPHb}$ complexes, bound to the receptor with an affinity of $1.7 \mu \mathrm{M}$, as determined by surface plasmon resonance (Figure 3B), comparable to the $0.7 \mu \mathrm{M}$ affinity of the receptor for $\mathrm{HpSPHb}$. This suggests that $\mathrm{HprHb}$, and as a result, TLF1, will have a shared binding mode with $\mathrm{HpHb}$.

\section{A model for haptoglobin-haemoglobin uptake in the context of the VSG layer}

The haptoglobin-haemoglobin receptor operates in the context of the VSG layer, a dense coat of surface protein that covers the trypansosome surface. It is therefore initially surprising that the 


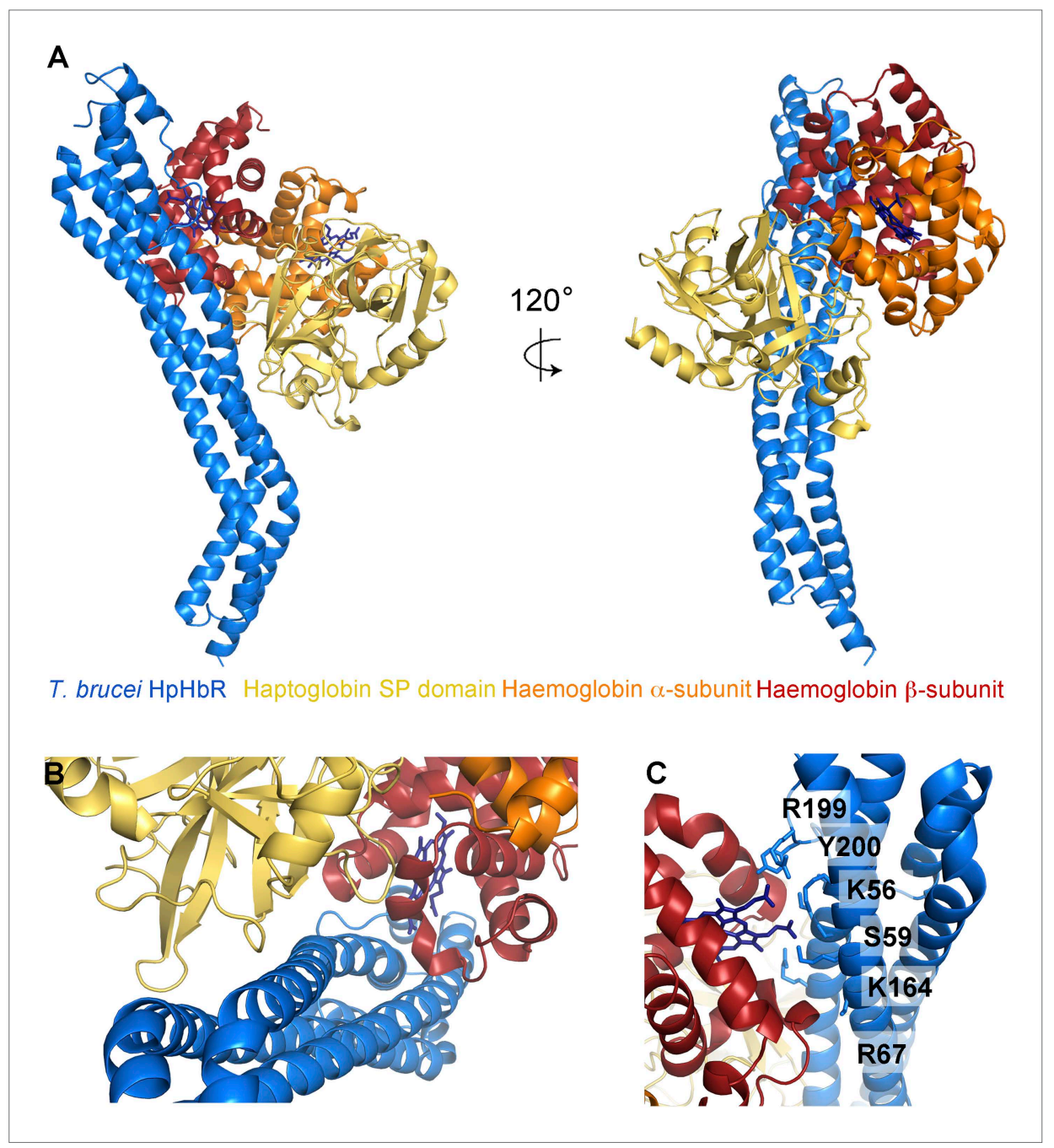

Figure 2. The structural basis for haptoglobin-haemoglobin binding by TbHpHbR. (A) The structure of the complex between T. brucei HpHbR (blue) bound to its ligand, $\mathrm{HpSPHb}$ (haptoglobin is yellow, the $\beta$-subunit of haemoglobin is red and the $\alpha$-subunit of haemoglobin is orange). (B) The complex viewed from the membrane proximal end, showing the contacts made by haptoglobin and the $\beta$-subunit of haemoglobin. (C) A view of the haemoglobinbinding site showing direct contacts between the haem and the receptor. Residues from the receptor that directly contact the haemoglobin subunit are shown as sticks and are numbered.

DOI: 10.7554/eLife.05553.008

The following figure supplements are available for figure 2:

Figure supplement 1. Stereoview of the TbHpHbR in complex with $\mathrm{HpHb}$. DOI: 10.7554/eLife.05553.009

Figure supplement 2. Small angle x-ray scattering of complexes of $\mathrm{TcHpHbR}$ and $\mathrm{TbHpHbR}$ with $\mathrm{HpSPHb}$. DOI: 10.7554/eLife.05553.010

Figure supplement 3. Clashes between $\mathrm{TbHpHbR}$ and a haemoglobin tetramer explain why the receptor does not bind to haemoglobin. DOl: 10.7554/eLife.05553.011

Figure supplement 4. The region affected by haptoglobin cleavage is not involved in interaction with $\mathrm{TbHpHbR}$. DOI: 10.7554/eLife.05553.012

location of the binding site for bulky HpHb complexes extends some $70 \AA$ from the membrane distal tip of the receptor and below the surface of the VSG layer. However, one consequence of the kink in the $T$. brucei receptor is to increase its effective diameter, pushing apart VSG molecules. In addition, the orientation of the kink is precisely arranged to increase exposure of the $\mathrm{HpHb}$ binding site to the surface, making it more accessible for ligand binding. 
Table 3. Small angle $x$-ray scattering statistics

\begin{tabular}{llllll} 
& $\mathbf{M W}(\mathbf{k D a})$ & $\mathbf{R}_{\mathbf{G}}(\mathbf{n m})$ & $\mathbf{D}_{\max }(\mathbf{n m})$ & Volume $^{\left(\mathbf{n m}^{3}\right)}$ & $\mathbf{M w}_{\mathbf{a p p}}(\mathbf{k D a})$ \\
\hline $\mathrm{HpSPHb}$ & 59.7 & 2.6 & 7.5 & 75 & 36 \\
\hline TbHpHbR & 32.2 & 3.5 & 11.5 & 44 & 22 \\
\hline TbHbHbR:HpSPHb & 91.8 & 3.2 & 10.8 & 110 & 55 \\
\hline TbHpHbR:HpSPHb & 89.6 & 3.8 & 12.0 & 140 & 70 \\
\hline $\mathrm{HpHb}$ & 152 & 5.6 & 18.2 & 214 & 107 \\
\hline TbHpHbR:HpHb & 217 & 6.3 & 16.5 & 370 & 185
\end{tabular}

DOI: 10.7554/eLife.05553.013

Docking of TbHpHbR:HpSPHb structures onto the structure of dimeric porcine $\mathrm{HpHb}$ reveals another consequence of the kink. This modelling suggests that two receptors can bind simultaneously to a single $\mathrm{HpHb}$ dimer, resulting in a C-shaped complex with a parallel arrangement of the membrane proximal parts of the two receptors (Figure 4A). Indeed, this arrangement was confirmed in solution by small angle x-ray scattering. Native (dimeric) human $\mathrm{HpHb}$ was mixed with $\mathrm{TbHpHbR}$, and gel filtration was performed, with SAXS data collected from samples as they emerged from the column. The resultant scattering curves confirmed the assembly of a complex containing two receptors and one $\mathrm{HpHb}$ in vitro. These data were used to generate a molecular envelope for the complex, which confirmed the C-shaped architecture (Figure 4B, Figure 4figure supplement 1, Table 3). Additional support for the formation of this complex in solution came from multi-angle laser light scattering (SEC-MALLS), which revealed masses of $30 \mathrm{kDa}$ for the receptor, $150 \mathrm{kDa}$ for $\mathrm{HpHb}$ and $210 \mathrm{kDa}$ for the complex, showing that two receptors bind to each $\mathrm{HpHb}$ in solution (Figure 4-figure supplement 2). This arrangement, in which two

Table 4. Interactions between TbHpHbR and $\mathrm{HpSPHb}$

\begin{tabular}{|c|c|c|c|c|c|}
\hline \multicolumn{2}{|c|}{ Receptor } & \multicolumn{3}{|c|}{ HpSPHb } & \multirow[b]{2}{*}{ Interaction } \\
\hline Residue & Group & Chain & Residue & Group & \\
\hline & & $\mathrm{Hb} \beta$ & & & \\
\hline K56 & side chain & B & Haem144 & O1D & Hydrogen bond \\
\hline E57 & side chain & B & K96 & Side chain & Salt bridge \\
\hline S59 & side chain & B & Haem144 & O1D/O2D & Hydrogen bond \\
\hline 160 & side chain & $B$ & Patch & & Hydrophobic \\
\hline R67 & side chain $\mathrm{NH} 1$ & $B$ & R41 & Backbone CO & Hydrogen bond \\
\hline E70 & side chain OE1/OE2 & B & R41 & Side chain NE/NH2 & Salt bridge \\
\hline S161 & side chain & B & $\mathrm{K} 60$ & Side chain & Hydrogen bond \\
\hline $\mathrm{S} 161$ & side chain & B & S45 & Backbone CO & Hydrogen bond \\
\hline K164 & side chain & B & Haem144 & O2D & Hydrogen bond \\
\hline R199 & side chain NE & B & Haem144 & $\mathrm{O} 2 \mathrm{~A}$ & Hydrogen bond \\
\hline Y200 & side chain $\mathrm{OH}$ & B & Haem144 & $\mathrm{O} 2 \mathrm{~A}$ & Hydrogen bond \\
\hline \multirow[t]{2}{*}{ S203 } & backbone $\mathrm{CO}$ & B & K96 & Side chain & Hydrogen bond \\
\hline & & HpSP & & & \\
\hline S73 & side chain & C & K345 & Side chain & Hydrogen bond \\
\hline V74 & hydrophobic & C & Patch & & Hydrophobic \\
\hline Q75 & OE1 & C & G276 & Backbone CO & Hydrogen bond \\
\hline A78 & side chain & C & Patch & & Hydrophobic \\
\hline A82 & side chain & C & Patch & & Hydrophobic \\
\hline K85 & side chain & C & D305 & Side chain O2D & Salt bridge \\
\hline
\end{tabular}

DOI: 10.7554/eLife.05553.014 


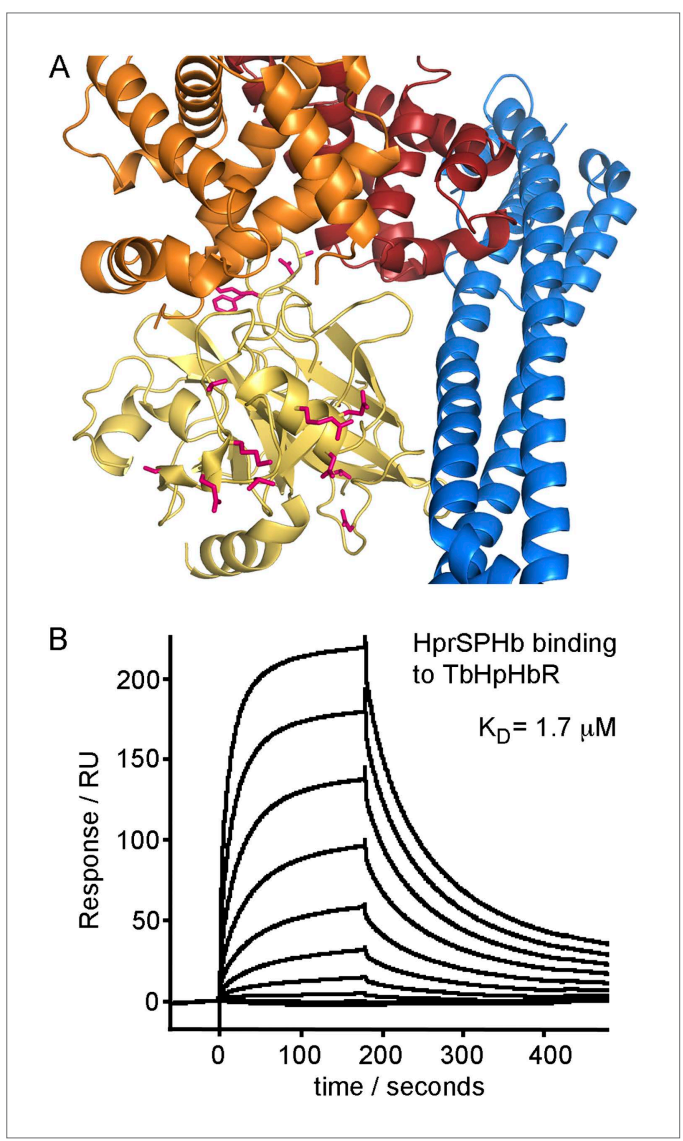

Figure 3. Differences between haptoglobin and haptoglobin-related protein do not alter affinity for TbHpHbR. (A) The structure of the TbHpHbR:HpSPHb complex is shown with the receptor in blue and haptoglobin in yellow. Side chains in haptoglobin that are different in haptoglobin-related protein are highlighted in pink and are not involved in making interactions with the receptor. (B) Surface plasmon resonance signals for two-fold dilutions of $\mathrm{HprSPHb}$ complex from a maximum concentration of $8 \mu \mathrm{M}$, binding to a surface coated with $T$. brucei $\mathrm{HpHbR}$. The measured affinity of $1.7 \mu \mathrm{M}$ can be compared with the affinity of $0.7 \mu \mathrm{M}$ for $\mathrm{HpSPHb}$. DOI: 10.7554/eLife.05553.015

simultaneous binding of two receptors to one $\mathrm{HpHb}$ ligand, increasing ligand avidity and uptake efficiency.

\section{Discussion}

The external surface of an African trypanosome is covered with a tightly packed layer of variant surface glycoprotein that shields epitopes that lie close to the plasma membrane from antibody binding (Schwede et al., 2011). Receptors such as those required for the uptake of transferrin and haptoglobin-haemoglobin complexes must operate within the context of this coat, with their structures organised such that ligand binding sites are not masked by the VSG layer.

Here, the first structure of a trypanosome receptor in complex with its ligand is presented: that of the T. brucei haptoglobin-haemoglobin receptor bound to haptoglobin-haemoglobin. Remarkably, the ligand-binding site extends more that half the way along the receptor, forming distinct binding surfaces for the $\beta$-subunit of haemoglobin and for haptoglobin. The simultaneous binding of both 


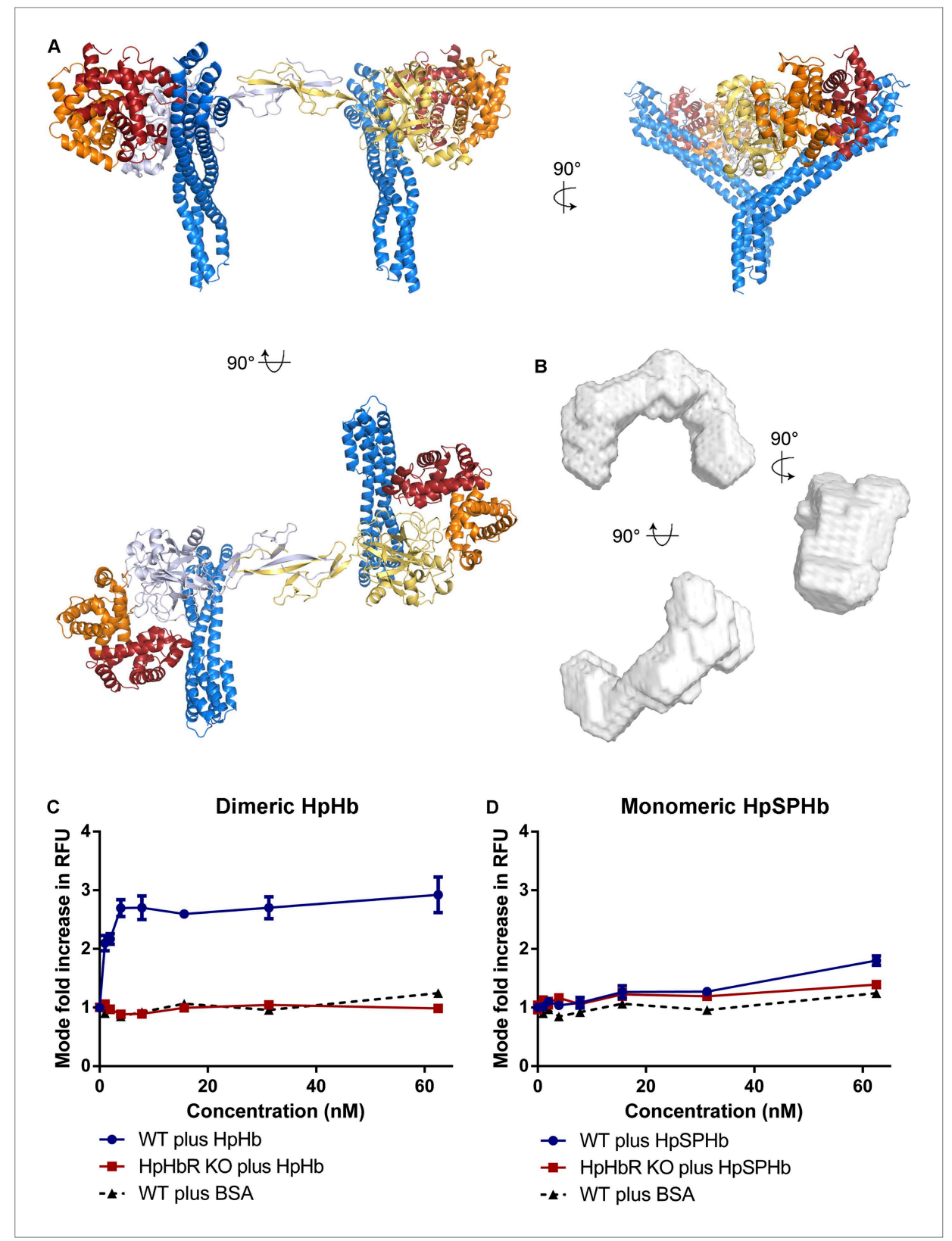

Figure 4. Simultaneous binding of two receptors to each $\mathrm{HpHb}$ dimer leads to more efficient uptake into trypanosomes. (A) A model for a complex of one $\mathrm{HpHb}$ dimer bound to two receptors, generated by docking the structure of the TbHpHbR:HpSPHb complex onto that of porcine $\mathrm{HpHb}$ (Andersen et al., 2012). The receptors are organized such that two receptors, both associated with the membrane through attachment at their C-termini, can simultaneously bind to one $\mathrm{HpHb}$ dimer. (B) An ab initio molecular envelope derived from small angle x-ray scattering analysis of the $\mathrm{TbHpHbR:HpHb}$ complex supports the formation of a complex containing one HpHb dimer bound to two receptors. (C) Uptake of fluorescently labelled dimeric $\mathrm{HpHb}$ into live cells was monitored via flow cytometry across a range of 1-62.5 $\mathrm{nM}$. Uptake saturated by $4 \mathrm{nM}$ in wild-type cells whereas no uptake was observed in the $\mathrm{HpHbR}$ null cell line. No fluid phase uptake of labelled BSA was observed at these concentrations. (D) Uptake of fluorescently labelled monomeric $\mathrm{HpSPHb}$ was not readily detected until $62.5 \mathrm{nM}$, at which point uptake had not saturated. $\mathrm{HpSPHb}$ uptake at $62.5 \mathrm{nM}$ was lost in the $\mathrm{HpHbR}$ null cell line. Each uptake assay was carried out in triplicate. Error bars represent standard error of the mean, $n=3$.

DOI: 10.7554/eLife.05553.016

The following figure supplements are available for figure 4:

Figure supplement 1. Small angle x-ray scattering of $\mathrm{HpHb}$, alone and in complex with TbHpHbR. DOI: 10.7554/eLife.05553.017

Figure 4. Continued on next page 
Figure 4. Continued

Figure supplement 2. SEC MALLS data to assess the stoichiometry of the TbHpHbR:HpHb complex. DOI: 10.7554/eLife.05553.018

Figure supplement 3. Establishment and characterization of an $\mathrm{HpHb}^{-/-}$cell line of $\mathrm{T}$. brucei. DOI: 10.7554/eLife.05553.019

components explains the specificity of the receptor for haptoglobin-haemoglobin complexes over each individual component. However, the extent of the binding surface places it below the top of the VSG layer, apparently increasing the likelihood that it will be masked by VSG.

However, a $\sim 50^{\circ}$ rigid kink occurs as an adaptation in the three helical bundle of the T. brucei receptor, and we propose that it has two main functional consequences. Firstly, the direction of the kink is precisely arranged to bend the receptor such that the ligand-binding site becomes more exposed at the membrane surface. The kink will also increase the effective diameter of the receptor in the plane of the membrane. This combination is likely to increase the separation of VSG molecules in the region of the receptor and to increase the accessibility of the binding site for bulky macromolecular ligands such as $\mathrm{HpHb}$ and trypanolytic factors. Increased separation of VSG molecules by a trypanosome receptor is not a novel phenomena, with bulky glycan chains attached to the transferrin receptor proposed to have a similar effect (Mehlert et alo, 2012), suggesting that different receptors increase the accessibility of binding sites for bulky ligands by different means.

The precise nature of the integration of TbHpHbR into the VSG layer remains unresolved as the effect of the C-terminal domains of both the receptor and VSG on the vertical disposition of each molecule remains unknown. An attractive model is that the ligand, whether HpHb or TLF1, is bound above the top of the VSG. However, the dimensions of the structures of VSG and the TbHpHbR:HpHb complex suggest that this may not be the case and that the $\mathrm{HpHb}$ ligand is held at least partially within the VSG layer (Figure 5). The TLF1 ligand is $\sim 4$ times the size of $\mathrm{HpHb}$ and this must, at least partially, protrude above the top of the VSG layer.

A second consequence of the kink is to allow two receptors to simultaneously bind to one dimeric $\mathrm{HpHb}$ complex when their membrane-proximal $\mathrm{C}$-termini are membrane-attached. The affinity of a single receptor for $\mathrm{HpHb}$ is modest, at $\sim 1 \mu \mathrm{M}$, with a rapid off-rate. By enabling two receptors to bind simultaneously, the kink will increase the ligand avidity, changing the effective affinity to something in the low nanomolar range, as previously measured for bivalent binding by TbHpHbR (Higgins et al., 2013) and to live cells (Drain et alo, 2001).

What is the likelihood of two receptors interacting with a single ligand on the cell surface? The receptor copy number is 200-400 and it is concentrated in the flagellar pocket (Vanhollebeke et al., 2008). The surface area of the flagellar pocket in live cells is $4.3 \mu \mathrm{m}^{2}$ (Grünfelder et al., 2002). If there are 200 receptor molecules in the membrane of the flagellar pocket then the density is one receptor per $0.022 \mu \mathrm{m}^{2}$. The diffusion constant for $\mathrm{HpHbR}$ is unknown, but the diffusion constant for another GPI-anchored protein, VSG, has been measured by fluorescence recovery after photobleaching to be $0.01 \mu \mathrm{m}^{2} / \mathrm{s}$ (Bulow et al., 1988); this means that the receptor will contact a receptor molecule approximately every $2 \mathrm{~s}$. The $t_{1 / 2}$ for release of monovalently bound $\mathrm{HpHb}$ is $70-100 \mathrm{~s}$ (Higgins et al., 2013) (Figure 1-figure supplement 1), so if it is assumed that the receptor has a similar diffusion coefficient to the VSG, then it is very likely that a monovalently bound ligand will become bivalently bound. Indeed our analysis of uptake of dimeric $\mathrm{HpHb}$ and monomeric $\mathrm{HpSPHb}$ into $\mathrm{T}$. brucei confirmed that this increased avidity does occur in vivo, with $\mathrm{HpHb}$ uptake saturating at a concentration below $4 \mathrm{nM}$, while $\mathrm{HpSPHb}$ uptake is far from saturation at $62.5 \mathrm{nM}$.

Whether other trypanosome receptors use a similar avidity-increase mechanism to improve the efficiency of ligand uptake remains to be seen, and whether it is required will depend upon the receptor affinity for monomer and the sera concentration of the nutrient. However, it is clear from the example of $\mathrm{TbHpHbR}$ that this mode of ligand binding is potentially applicable to other GPIanchored cell surface proteins.

While the evolution of the kink allows increased accessibility of the binding site for $\mathrm{HpHb}$, it would also increase accessibility for the large TLF1 complex. One mechanism used by human infective T. b. gambiense to avoid TLF1-mediated innate immunity is a point polymorphism in $\mathrm{HpHbR}$ that reduces the monovalent affinity for $\mathrm{HpHb}$ by 20 -fold (Higgins et al., 2013) and reduces TLF1 uptake (Kieft et al., 2010). It remains to be seen whether TLF1 contains one or multiple HprHb 


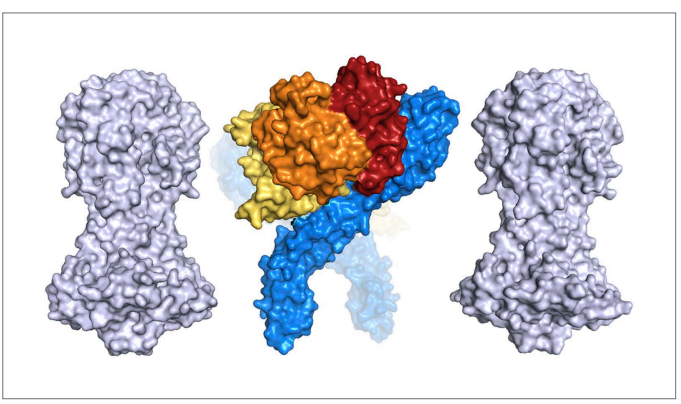

Figure 5. A comparison of the dimensions of the TbHpHbR:HpHb complex with those of the N-terminal domains of the variant surface glycoproteins (shown in grey). This suggests that $\mathrm{HpHb}$ will lie at least partially within the VSG layer when bound to two receptors. DOI: 10.7554/eLife.05553.020

These questions will need further study.

In conclusion, we present the first structure of a trypanosome receptor in complex with its ligand and reveal a number of adaptations that are tailored to facilitate efficient ligand binding in the context of the VSG coat. These will decrease the packing of VSG molecules in the immediate vicinity of the receptor and increase accessibility of the ligand-binding site. They also allow two receptors to bind to a single ligand, thereby increasing avidity and dramatically decreasing the ligand concentration at which efficient uptake occurs. While different adaptations might facilitate each of these goals in different receptors, we would expect them to be general principles, frequently used by the parasite to aid nutrient uptake and survival.

\section{Materials and methods}

\section{T. brucei HpHbR cloning, expression and purification}

Full-length T. b. brucei $\mathrm{HpHbR}$, without the $\mathrm{N}$-terminal signal sequence and C-terminal GPI-anchor addition sequence, had been previously cloned for expression in a modified pET-15b to generate a polypeptide with an $\mathrm{N}$-terminal hexahistidine tag and a cleavage site for TEV protease (Higgins et al., 2013). To produce a truncated construct for expression of the $N$-terminal ligand-binding domain, a stop codon was inserted after residue R299 using a polymerase chain reaction based mutagenesis protocol, using oligonucleotide GAGATGAAGCGCTAGGGGAACCCGATC and its reverse-complement. Mutagenesis was carried out as described for the Quikchange mutagenesis method (Stratagene, La Jolla, CA) and the plasmid was sequence verified.

The protein was expressed in E. coli Origami B, induced with $1 \mathrm{mM}$ IPTG and incubated overnight at $18^{\circ} \mathrm{C}$. The protein was purified by $\mathrm{Ni}^{2+}-\mathrm{NTA}$ affinity chromatography and cleaved overnight with his-tagged TEV protease at $4^{\circ} \mathrm{C}$ in PBS with $3 \mathrm{mM}$ oxidized glutathione, $0.3 \mathrm{mM}$ reduced glutathione, followed by reverse $\mathrm{Ni}^{2+}$-NTA affinity chromatography. The protein was concentrated by Amicon Ultra centrifugal filter device (10,000 MWCO) (EMD Millipore, Billerica, MA) and gel filtered using a Superdex 75 16/60 column (Life Technologies, Carlsbad, CA) into 20 mM HEPES $\mathrm{pH} 7.5,150 \mathrm{mM} \mathrm{NaCl}$.

\section{HpSP and HprSP cloning, expression and purification}

Synthetic genes encoding the SP domains of human $\mathrm{Hp}$ (148-406) and $\mathrm{Hpr}$ (90-348) were cloned into a modified pAcGP67A vector to generate a polypeptide with an $\mathrm{N}$-terminal hexahistidine tag and a cleavage site for TEV protease. These were transfected into Sf9 insect cells using the BaculoGold Baculovirus DNA transfection protocol (BD Biosciences, Franklin Lakes, NJ). Following selection of virus using plaque assays, the third amplification of recombinant virus was used to infect Sf9 insect cells. After 3 days, the cells were centrifuged for $15 \mathrm{~min}$ at $6000 \times \mathrm{g}$. After filtering, the supernatant was buffer exchanged into $20 \mathrm{mM}$ Tris $\mathrm{pH} 8,300 \mathrm{mM} \mathrm{NaCl}$ using a tangential flow apparatus (Pall Corporation, Port Washington, NY), followed by $\mathrm{Ni}^{2+}-\mathrm{NTA}$ affinity chromatography. The protein was 
concentrated using an Amicon Ultra centrifugal filter device (10,000 MWCO) (EMD Millipore). When used for crystallisation, HpSP was deglycosylated by incubation with endoglycosidase Hf (SigmaAldrich, St Louis, MO) and endoglycosidase $\mathrm{F} 3$ at enzyme:protein ratios of 1:25 in $1 \mathrm{mM} \mathrm{CaCl}, 1 \mathrm{mM}$ $\mathrm{MgCl}_{2}, 100 \mathrm{mM} \mathrm{HEPES} \mathrm{pH} 7.5$ at $37^{\circ} \mathrm{C}$ for $3 \mathrm{hr}$.

\section{Purification of $\mathrm{Hb}$ and formation of the $\mathrm{HpHb}$ complex}

$\mathrm{Hb}$ was isolated from human blood by sonication, followed by anion exchange chromatography using a Mono $\mathrm{Q}$ column (Life Technologies). $\mathrm{HpHb}$ was made by mixing full-length $\mathrm{Hp}$ 1-1 (Sigma-Aldrich) with purified $\mathrm{Hb}$ and isolating the complex by gel filtration using a Superdex 200 16/60 column (Life Technologies) in $20 \mathrm{mM}$ HEPES pH 7.5, $150 \mathrm{mM} \mathrm{NaCl}$.

\section{$\mathrm{HpSPHb}$ and HprSPHb complex formation}

$\mathrm{HpSP}$ or $\mathrm{HprSP}$ at a threefold molar excess was mixed with $\mathrm{Hb}$ and diluted fivefold into $20 \mathrm{mM}$ Tris $\mathrm{pH}$ $8,500 \mathrm{mM} \mathrm{NaCl}, 15 \mathrm{mM}$ imidazole. The complex was purified by $\mathrm{Ni}^{2+}-\mathrm{NTA}$ affinity chromatography, washed using the dilution buffer, and eluted into PBS containing $200 \mathrm{mM}$ imidazole. The complexes were then concentrated using an Amicon Ultra centrifugal filter device $(10,000$ MWCO) (EMD Millipore), and purified by gel filtration using a Superdex 200 16/60 column (Life Technologies) in $20 \mathrm{mM}$ HEPES $\mathrm{pH}$ 7.5, $150 \mathrm{mM} \mathrm{NaCl}$.

\section{Crystallisation, data collection and structure determination of the HpSPHb complex}

$\mathrm{HpSPHb}$ was concentrated to $15 \mathrm{mg} \mathrm{ml}^{-1}$ for crystallization. Crystals were obtained after $8 \mathrm{hr}$ in sitting drops with a well solution containing $0.2 \mathrm{M} \mathrm{NaCl}, 0.1 \mathrm{M}$ sodium cacodylate $\mathrm{pH} 6.5$ and $2 \mathrm{M}$ ammonium sulphate. These were cryoprotected by transfer into well solution with the addition of $30 \% \mathrm{vol} / \mathrm{vol}$ glycerol before cryo-cooling using liquid nitrogen. Data were collected on beamline 104-1 at the Diamond light source and were integrated and scaled using iMosflm (Battye et al., 2011) and scala (Evans, 1993) from the CCP4 suite (Winn et al., 2011), giving a final resolution of $2.05 \AA$. The structure was determined by molecular replacement using Phaser (McCoy et al., 2007) with the equivalent region of the porcine $\mathrm{HpHb}$ (pdb: 4F4O) as a search model. The structure was rebuilt and refined using Coot (Emsley et al., 2010) and REFMAC (Murshudov et al., 2011).

\section{Crystallisation, data collection and structure determination of the TbHpHbR:HpSPHb complex}

$\mathrm{TbHpHbR}$ was mixed with HpSPHb and purified by gel filtration using a Superdex $20016 / 600$ column (Life Technologies) into a buffer containing $150 \mathrm{mM} \mathrm{NaCl}$ and $20 \mathrm{mM} \mathrm{HEPES} \mathrm{pH} \mathrm{7.5.} \mathrm{It} \mathrm{was}$ concentrated to a final concentration of $15 \mathrm{mg} \mathrm{ml}^{-1}$ and crystallised at $18{ }^{\circ} \mathrm{C}$ using sitting drops with a well solution containing $12.5 \% \mathrm{vol} / \mathrm{vol} \mathrm{MPD}, 0.03 \mathrm{M} \mathrm{NaBr}, 0.03 \mathrm{M} \mathrm{Nal}, 0.03 \mathrm{M} \mathrm{NaF}, 0.1 \mathrm{M}$ MES/imidazole pH 6.5, 12.5\% wt/vol PEG 1000, 12.5\% wt/vol PEG 3350 from the Morpheus screen (Molecular Dimensions, UK). Crystals formed after 10 days. Seed beads (Hampton Research, Aliso Viejo, CA) were used to create seeds from these crystals. These were used to seed a plate containing $100 \mathrm{nl}$ of protein, $50 \mathrm{nl}$ of the Morpheus well solution, and $50 \mathrm{nl}$ of the Silver Bullet additive screen (Hampton Research). Crystals grew after 8 days in the well containing additives $0.2 \%$ wt/ vol 2,2'-thiodiglcolic acid, $0.2 \% \mathrm{wt} / \mathrm{vol}$ apidic acid, $0.2 \% \mathrm{wt} / \mathrm{vol}$ benzoic acid, $0.2 \% \mathrm{wt} / \mathrm{vol}$ oxalic acid anhydrous, $0.2 \% \mathrm{wt} / \mathrm{vol}$ terephthalic acid. These were cryo-cooled in liquid nitrogen in the Morpheus well solution.

Data were collected on beamline 103 at the Diamond light source. Data reduction was performed using XDS (Kabsch, 2010) and the structure was solved by molecular replacement with the HpSPHb structure as a search model using Phaser (McCoy et alo, 2007). Automatic model building in Buccaneer (Cowtan, 2006) was used to identify the positions of the receptor helices, leading to a cycle of model building and refinement in Coot (Emsley et al., 2010) and Buster (Bricogne et al., 2011). The coordinates from the higher resolution structures of both and $\mathrm{TbHpHbR}$, also determined during this study, were used to provide restraints during refinement, leading to improved stereochemistry of the resultant model.

\section{Crystallisation, data collection and structure determination of TbHpHbR}

The receptor was concentrated to $12.5 \mathrm{mg} \mathrm{ml}^{-1}$ for crystallization. Crystals were obtained at $18{ }^{\circ} \mathrm{C}$ after 7 days using sitting drops with a well solution of $0.15 \mathrm{M} \mathrm{KBr}, 30 \% \mathrm{wt} / \mathrm{vol}$ PEG $2000 \mathrm{MME}$ from 
the JCSG+ screen (Molecular Dimensions). These were partially dehydrated and cryoprotected by transfer into the well condition with addition of $30 \% \mathrm{vol} / \mathrm{vol}$ glycerol before cryo-cooling in liquid nitrogen.

Data were collected on beamline 103 at the Diamond light source. Data reduction was performed using iMosflm (Battye et al., 2011) and scala (Evans, 1993) from the CCP4 data processing suite (Winn et al., 2011). Molecular replacement was performed using Phaser (McCoy et al., 2007), with the structure of TbHpHbR taken from the TbHpHbR:HpSPHb complex as a search model. A cycle of refinement and model building was carried out using REFMAC (Murshudov et al., 2011) and Coot (Emsley et al., 2010).

\section{Small-angle X-ray scattering (SAXS) data collection and processing}

SAXS data for TbHpHbR alone and in complex with $\mathrm{HpSPHb}$, and for the complex of $\mathrm{TcHpHbR}$ with HpSPHb, were collected at the Petralll P12 beamline at Deutsches Elektronen-Synchrotron using a wavelength of $1.24 \AA$. SAXS data for the complex of the receptor with dimeric $\mathrm{HpHb}$ were collected at beamline BM29 at the European Synchrotron Radiation Facility using a wavelength of $0.9 \AA$. SAXS data for $\mathrm{HpHb}$ alone was collected at beamline B21 at the Diamond Light Source with a wavelength of $1.0 \AA$. In all cases, scattering was detected using a Pilatus image reader at $20^{\circ} \mathrm{C}$.

The receptors alone and in complex with $\mathrm{HpSPHb}$, as well as $\mathrm{HpHb}$ alone, were prepared at concentrations of 2.0, 1.0, 0.5, 0.25 and $0.125 \mathrm{mg} \mathrm{ml}^{-1}$ in $20 \mathrm{mM}$ HEPES pH 7.5, $150 \mathrm{mM} \mathrm{NaCl}$. Twenty consecutive frames of $10 \mathrm{~s}$ each were recorded for each protein sample with a buffer sample measured between each, except $\mathrm{HpHb}$, for which 180 consecutive $1 \mathrm{~s}$ frames were taken. Any images where the data had been affected by protein radiation damage were excluded from further processing.

The complex with dimeric $\mathrm{HpHb}$ was prepared and analysed by size-exclusion column (SEC)SAXS, using a Superdex 200 10/300 column (Life Technologies) in $20 \mathrm{mM}$ HEPES pH 7.5, 150 mM $\mathrm{NaCl}$ with a running speed of $0.4 \mathrm{ml} \mathrm{min}{ }^{-1}$. One frame was collected every $2 \mathrm{~s}$. Frames corresponding to the peak seen on the UV trace were selected and a curve representing the scattering due to buffer was produced by averaging ten frames from the beginning of the run.

For each data set, PRIMUS (Konarev et al., 2003; Petoukhov et al., 2007) was used to normalize data to the intensity of the incident beam, for averaging of equivalent images and to subtract scattering due to buffer. Where Guinier plots revealed aggregation due to high concentration, data were removed (Guinier and Fournet, 1955). Composite curves were generated by scaling and merging the data sets.

AutoRg calculated the distance distribution function $(P(r))$ using an indirect Fourier transform, allowing estimation of the radius of gyration $\left(R_{g}\right)$, the maximum particle dimension $\left(D_{\max }\right)$ and the Porod volume (Porod, 1982) by GNOM (Petoukhov et al., 2007). Initial models of the shape were generated using DAMMIF (Franke and Svergun, 2009) and averaged using the DAMAVER programme suite (Konarev et al., 2006). DAMMIN then produced a final model by minimising differences between experimental data and scattering of the model. The envelope model was produced using Situs (Birmanns et al., 2011), and feature-based docking of the crystal structures was completed using Sculptor (Birmanns et al., 2011).

\section{Surface plasmon resonance}

Measurements were performed on a Biacore T200 (Life Technologies) instrument with a constant flow rate of $30 \mu \mathrm{g} \mathrm{ml}^{-1}$. A CM5 chip was prepared by flowing over a 1:1 mixture of ethyl-dimethylaminopropyl-carbodiimide and $\mathrm{N}$-hydroxysuccinimide. TbHpHbR was diluted into $10 \mathrm{mM}$ sodium acetate $\mathrm{pH} 5$ to a final concentration of $0.1 \mu \mathrm{M}$.

Ligands were diluted into HBS $(20 \mathrm{mM}$ HEPES $\mathrm{pH} 7.5,150 \mathrm{mM} \mathrm{NaCl}, 0.005 \% \mathrm{vol} / \mathrm{vol}$ Tween 20). Both channels were equilibrated with HBS before injection of binding partner, and the level of specific binding obtained from a subtraction of the response from channel 2 from that of channel 1. Values for $K_{D}$ were obtained by equilibrium binding analysis using the BIAevaluation software.

\section{Size exclusion chromatography-multiangle laser light scattering}

Purified samples were loaded onto a Superose 6 10/300 column (GE Healthcare), then analysed using laser light scattering detected at $662 \mathrm{~nm}$ wavelength at 8 scattering angles between $20.6^{\circ}$ and 
149. $1^{\circ}$ using a Heleos 8 instrument (Wyatt Technology, Germany). ASTRA 6.1 (Wyatt Technology) was used to calculate molecular weights using the Zimm equation. The samples were loaded at concentrations of $10 \mu \mathrm{M}$ for $\mathrm{HpHb}$ and $40 \mu \mathrm{M}$ for TbHpHbR.

\section{Trypanosome cell culture and construction of T. brucei $\mathrm{HpHbR}^{-/-}$ cell line}

T. brucei blood stream form cells were grown in $\mathrm{HMI}-9$ at $37{ }^{\circ} \mathrm{C}$ with $5 \% \mathrm{CO}_{2}$ (Hirumi and Hirumi, 1989). The linear DNAs used to replace $\mathrm{HpHbR}$ genes by homologous recombination were produced by PCR. First, one allele was replaced in procyclic form Lister 427 cells using a PCR product that contained $80 \mathrm{bp}$ from upstream of the $\mathrm{HpHbR}$ gene, followed by the blasticin resistance cassette, followed by $80 \mathrm{bp}$ from downstream of the HpHbR gene. The same approach was used with a G418 resistance cassette. Genomic DNA was prepared from blasticin or G418 resistant cell lines and used as a template for a PCR using oligonucleotides $500 \mathrm{bp}$ upstream and downstream of the HpHbR gene. These second PCR products were used to serially transfect Lister 427 bloodstream form cells expressing VSG118.

\section{Uptake assays for monitoring uptake of fluorescently labelled ligands into live cells}

When used for uptake experiments, Hp, HpSP and BSA were labelled with Alexa Fluor 488 using the protein labelling kit (Life Technologies). The manufacturer's protocol was adapted, extending the reaction time to overnight at $4{ }^{\circ} \mathrm{C}$ to increase labelling efficiency. $\mathrm{Hp}$ and $\mathrm{HpSP}$ were then subsequently mixed with $\mathrm{Hb}$ to form complex as above. For each assay, $5 \times 10^{6}$ wild type Lister 427 or $\mathrm{HpHbR^{-1- }}$ cells were resuspended in $100 \mu \mathrm{l}$ of serum free $\mathrm{HMI}-9$ with $1 \% \mathrm{BSA}$ and incubated with $2 \mu \mathrm{M}$ protease inhibitor FMK-024 for $10 \mathrm{~min}$ at $37^{\circ} \mathrm{C}$. Cells were then incubated with 1-62.5 nM fluorescently labelled protein for $2 \mathrm{hr}$ at $37^{\circ} \mathrm{C}$ before being washed twice in serum free HMI-9 with 1\% BSA. Cells were fixed in $4 \%$ paraformaldehyde for $10 \mathrm{~min}$ at room temperature and resupended in PBS. Uptake was assayed by flow cytometry using a FACScan (BD Biosciences) and quantified on FlowJo software. Mode increase in fluorescence was measured relative to a no ligand negative control, and all assays were carried out in triplicate.

\section{Acknowledgements}

This work was supported by Medical Research Council Project Grant MR/L008246. HL is funded by the Wellcome Trust PhD program in Structural Biology. MKH is a Wellcome Investigator. We thank David Staunton for help with biophysical methods and Paul McKean (Lancaster University) for the gene deletion method. The structures are deposited in the protein data bank as 4XOI, 4XOJ and 4 XOL.

\section{Additional information}

\begin{tabular}{lll} 
Funding & $\begin{array}{l}\text { Grant reference } \\
\text { number }\end{array}$ & Author \\
\hline Medical Research Council & MR/L008246/1 & $\begin{array}{l}\text { Paula MacGregor, } \\
\text { Edward D Lowe, } \\
\text { Mark Carrington, } \\
\text { Matthew K Higgins }\end{array}$ \\
& & $\begin{array}{l}\text { Harriet Lane-Serff, } \\
\text { Wellcome Trust }\end{array}$ \\
& $101020 /$ Z/13/Z & Matthew K Higgins \\
\hline
\end{tabular}

The funders had no role in study design, data collection and interpretation, or the decision to submit the work for publication.

Author contributions

HL-S, MKH, PMG, Conception and design, Acquisition of data, Analysis and interpretation of data, Drafting or revising the article; EDL, Acquisition of crystallographic data; MC, Conception and design, Analysis and interpretation of data, Drafting or revising the article 


\section{Additional files}

Major datasets

The following datasets were generated:

\begin{tabular}{|c|c|c|c|c|}
\hline Author(s) & Year & Dataset title & Dataset ID and/or URL & $\begin{array}{l}\text { Database, license, } \\
\text { and accessibility } \\
\text { information }\end{array}$ \\
\hline $\begin{array}{l}\text { Lane-Serff H, MacGregor P, } \\
\text { Lowe ED, Carrington M, } \\
\text { Higgins MK }\end{array}$ & 2014 & $\begin{array}{l}\text { Trypanosoma brucei } \\
\text { haptoglobin-haemoglobin } \\
\text { receptor in complex } \\
\text { with human haptoglobin- } \\
\text { haemoglobin }\end{array}$ & $\begin{array}{l}\text { http://www.pdb.org/ } \\
\text { pdb/explore/explore. } \\
\text { do?structureld=4XOI }\end{array}$ & $\begin{array}{l}\text { Publicly available } \\
\text { at RCSB Protein } \\
\text { Data Bank. }\end{array}$ \\
\hline $\begin{array}{l}\text { Lane-Serff H, MacGregor P, } \\
\text { Lowe ED, Carrington M, } \\
\text { Higgins MK }\end{array}$ & 2014 & $\begin{array}{l}\text { Trypanosoma brucei } \\
\text { haptoglobin-haemoglobin } \\
\text { receptor }\end{array}$ & $\begin{array}{l}\text { http://www.pdb.org/ } \\
\text { pdb/explore/explore. } \\
\text { do?structureld=4XOJ }\end{array}$ & $\begin{array}{l}\text { Publicly available } \\
\text { at RCSB Protein } \\
\text { Data Bank. }\end{array}$ \\
\hline $\begin{array}{l}\text { Lane-Serff H, MacGregor P, } \\
\text { Lowe ED, Carrington M, } \\
\text { Higgins MK }\end{array}$ & 2014 & $\begin{array}{l}\text { Human haptoglobin- } \\
\text { haemoglobin complex }\end{array}$ & $\begin{array}{l}\text { http://www.pdb.org/ } \\
\text { pdb/explore/explore. } \\
\text { do?structureld=4XOL }\end{array}$ & $\begin{array}{l}\text { Publicly available } \\
\text { at RCSB Protein } \\
\text { Data Bank. }\end{array}$ \\
\hline
\end{tabular}

The following previously published dataset was used:

Database, license,

\begin{tabular}{|c|c|c|c|c|}
\hline Author(s) & Year & Dataset title & Dataset ID and/or URL & $\begin{array}{l}\text { and accessibility } \\
\text { information }\end{array}$ \\
\hline $\begin{array}{l}\text { Andersen } C B \text {, } \\
\text { Torvund-Jensen M, } \\
\text { Nielsen MJ, de Oliveira CL, }\end{array}$ & 2012 & $\begin{array}{l}\text { Structure of the } \\
\text { Haptoglobin-Haemoglobin } \\
\text { Complex }\end{array}$ & $\begin{array}{l}\text { http://www.pdb.org/ } \\
\text { pdb/explore/explore. } \\
\text { do?structureld=4F4O }\end{array}$ & $\begin{array}{l}\text { Publicly available } \\
\text { at RCSB Protein } \\
\text { Data Bank. }\end{array}$ \\
\hline
\end{tabular}

Hersleth HP, Andersen NH,

Pedersen JS, Andersen GR,

Moestrup SK

\section{References}

Andersen CB, Torvund-Jensen M, Nielsen MJ, de Oliveira CL, Hersleth HP, Andersen NH, Pedersen JS, Andersen GR, Moestrup SK. 2012. Structure of the haptoglobin-haemoglobin complex. Nature 489:456-459. doi: 10.1038/nature11369.

Battye TG, Kontogiannis L, Johnson O, Powell HR, Leslie AG. 2011. iMOSFLM: a new graphical interface for diffraction-image processing with MOSFLM. Acta Crystallographica. Section D, Biological Crystallography D67:271-281.

Birmanns S, Rusu M, Wriggers W. 2011. Using Sculptor and Situs for simultaneous assembly of atomic components into low-resolution shapes. Journal of Structural Biology 173:428-435. doi: 10.1016/j.jsb. 2010.11.002.

Bricogne G, Blanc E, Brandl M, Flensburg C, Keller P, Paciorek W, Roversi P, Sharff A, Smart OS, Vonrhein C, Womack TO. 2011. BUSTER version 2.10.0. Cambridge, UK: Global Phasing Ltd.

Bulow R, Overath P, Davoust J. 1988. Rapid lateral diffusion of the variant surface glycoprotein in the coat of Trypanosoma brucei. Biochemistry 27:2384-2388. doi: 10.1021/bi00407a020.

Capewell P, Clucas C, DeJesus E, Kieft R, Hajduk S, Veitch N, Steketee PC, Cooper A, Weir W, MacLeod A. 2013. The TgsGP gene is essential for resistance to human serum in Trypanosoma brucei gambiense. PLOS Pathogens 9:e1003686. doi: 10.1371/journal.ppat.1003686.

Cowtan K. 2006. The Buccaneer software for automated model building. Acta Crystallographica. Section D, Biological Crystallography D62:1002-1011. doi: 10.1107/S0907444906022116.

Drain J, Bishop JR, Hajduk SL. 2001. Haptoglobin-related protein mediates trypanosome lytic factor binding to trypanosomes. The Journal of Biological Chemistry 276:30254-30260. doi: 10.1074/jbc.M010198200.

Emsley P, Lohkamp B, Scott WG, Cowtan K. 2010. Features and development of Coot. Acta Crystallographica. Section D, Biological Crystallography D66:486-501. doi: 10.1107/S0907444910007493.

Engstler M, Pfohl T, Herminghaus S, Boshart M, Wiegertjes G, Heddergott N, Overath P. 2007. Hydrodynamic flow-mediated protein sorting on the cell surface of trypanosomes. Cell 131:505-515. doi: 10.1016/j. cell.2007.08.04615.

Evans PR. 1993. Data reduction. In: Sawyer L, Isaacs N, Bailey S, editors. Proceedings of the CCP4 Study Weekend. Warrington, UK: Daresbury Laboratory. p. 114-122.

Franke D, Svergun DI. 2009. DAMMIF, a program for rapid ab-initio shape determination in small-angle scattering. Journal of Applied Crystallography 42:342-346. doi: 10.1107/S0021889809000338.

Grünfelder CG, Engstler M, Weise F, Schwarz H, Stierhof YD, Boshart M, Overath P. 2002. Accumulation of a GPI-anchored protein at the cell surface requires sorting at multiple intracellular levels. Traffic 3:547-559. doi: 10.1034/j.1600-0854.2002.30805.x.

Guinier A, Fournet G. 1955. Small-Angle Scattering of X-rays: Wiley. 
Hager KM, Pierce MA, Moore DR, Tytler EM, Esko JD, Hajduk SL. 1994. Endocytosis of a cytotoxic human high density lipoprotein results in disruption of acidic intracellular vesicles and subsequent killing of African trypanosomes. The Journal of Cell Biology 126:155-167. doi: 10.1083/jcb.126.1.155.

Higgins MK, Tkachenko O, Brown A, Reed J, Raper J, Carrington M. 2013. Structure of the trypanosome haptoglobin-hemoglobin receptor and implications for nutrient uptake and innate immunity. Proceedings of the National Academy of Sciences of USA 110:1905-1910. doi: 10.1073/pnas.1214943110.

Hirumi H, Hirumi K. 1989. Continuous cultivation of Trypanosoma brucei blood stream forms in a medium containing a low concentration of serum protein without feeder cell layers. The Journal of Parasitology 75:985-989. doi: 10.2307/3282883.

Horn D. 2014. Antigenic variation in African trypanosomes. Molecular and Biochemical Parasitology 195:123-129. doi: 10.1016/j.molbiopara.2014.05.001.

Jackson AP, Allison HC, Barry JD, Field MC, Hertz-Fowler C, Berriman M. 2013. A cell-surface phylome for African trypanosomes. PLOS Neglected Tropical Diseases 7:e2121. doi: 10.1371/journal.pntd.0002121.

Kabsch W. 2010. XDS. Acta Crystallographica. Section D, Biological Crystallography D66:125-132. doi: 10.1107/ S0907444909047337.

Kieft R, Capewell P, Turner CM, Veitch NJ, MacLeod A, Hajduk S. 2010. Mechanism of Trypanosoma brucei gambiense (group 1) resistance to human trypanosome lytic factor. Proceedings of the National Academy of Sciences of the USA 107:16137-16141. doi: 10.1073/pnas.1007074107.

Konarev PV, Volkov VV, Sokolova AV, Koch MHJ, Svergun DI. 2003. PRIMUS: a Windows PC-based system for small-angle scattering data analysis. Journal of Applied Crystallography 36:1277-1282. doi: 10.1107/ S0021889803012779.

Konarev PV, Petoukhov MV, Volkov VV, Svergun DI. 2006. ATSAS 2.1, a program package for small-angle scattering data analysis. Journal of Applied Crystallography 39:277-286. doi: 10.1107/S0021889806004699.

Laveran A. 1902. De l'action du sérum humain sur le trypanosome de Nagana (Tr. brucei). Comptes Rendus Des Séances De l'Académie Des Sciences. Série III, Sciences De La Vie 134:735-739.

MacGregor P, Savill NJ, Hall D, Matthews KR. 2011. Transmission stages dominate trypanosome within-host dynamics during chronic infections. Cell Host \& Microbe 9:310-318. doi: 10.1016/j.chom.2011.03.013.

McCoy AJ, Grosse-Kunstleve RW, Adams PD, Winn MD, Storoni LC, Read RJ. 2007. Phaser crystallographic software. Journal of Applied Crystallography 40:658-674. doi: 10.1107/S0021889807021206.

Mehlert A, Wormald MR, Ferguson MA. 2012. Modeling of the N-glycosylated transferrin receptor suggests how transferrin binding can occur within the surface coat of Trypanosoma brucei. PLOS Pathogens 8:e1002618. doi: 10.1371/journal.ppat.1002618.

Murshudov GN, Skubak P, Lebedev AA, Pannu NS, Steiner RA, Nicholls A, Winn MD, Long F, Vagin AA. 2011. REFMAC5 for the refinement of macromolecular crystal structures. Acta Crystallographica. Section D, Biological Crystallography 67:355-367. doi: 10.1107/S0907444911001314.

Mussmann R, Engstler M, Gerrits H, Kieft R, Toaldo CB, Onderwater J, Koerten H, van Luenen HG, Borst P. 2004. Factors affecting the level and localization of the transferrin receptor in Trypanosoma brucei. The Journal of Biological Chemistry 279:40690-40698. doi: 10.1074/jbc.M404697200.

Pal A, Hall BS, Jeffries TR, Field MC. 2003. Rab5 and Rab11 mediate transferrin and anti-variant surface glycoprotein antibody recycling in trypanosoma brucei. The Biochemical Journal 374:443-451. doi: 10.1042/ BJ20030469.

Pays E, Vanhollebeke B. 2009. Human innate immunity against African trypanosomes. Current Opinion in Immunology 21:493-498. doi: 10.1016/j.coi.2009.05.024.

Pays E, Vanhollebeke B, Uzureau P, Lecordier L, Pérez-Morga D. 2014. The molecular arms race between African trypanosomes and humans. Nature Reviews. Microbiology 12:575-584. doi: 10.1038/nrmicro3298.

Pérez-Morga D, Vanhollebeke B, Paturiaux-Hanocq F, Nolan DP, Lins L, Homblé F, Vanhamme L, Tebabi P, Pays A, Poelvoorde P, Jacquet A, Brasseur R, Pays E. 2005. Apolipoprotein L-I promotes trypanosome lysis by forming pores in lysosomal membranes. Science 309:469-472. doi: 10.1126/science.1114566.

Petoukhov MV, Konarev PV, Kikhney AG, Svergun DI. 2007. ATSAS 2.1-towards automated and web-supported small-angle scattering data analysis. Journal of Applied Crystallography 40:s223-s228. doi: 10.1107/ S0021889807002853.

Porod G. 1982. General Theory Small Angle X-ray Scattering: Academic Press.

Raper J, Nussenzweig V, Tomlinson S. 1996. The main lytic factor of Trypanosoma. b. brucei in normal human serum is not high density lipoprotein. The Journal of Experimental Medicine 183:1023-1030. doi: 10.1084/ jem.183.3.1023.

Raper J, Fung R, Ghiso G, Nussenzweig V, Tomlinson S. 1999. The characterisation of a novel trypanosome lytic factor in human serum. Infection and Immunity 67:1910-1916.

Schell D, Evers R, Preis D, Ziegelbauer K, Kiefer H, Lottspeich F, Cornelissen AW, Overath P. 1991. A transferrinbinding protein of Trypanosoma brucei is encoded by one of the genes in the variant surface glycoprotein gene expression site. The EMBO Journal 10:1061-1066.

Schwede A, Carrington M. 2010. Bloodstream form Trypanosome plasma membrane proteins: antigenic variation and invariant antigens. Parasitology 137:2029-2039. doi: 10.1017/S0031182009992034.

Schwede A, Jones N, Engstler M, Carrington M. 2011. The VSG C-terminal domain is inaccessible to antibodies on live trypanosomes. Molecular and Biochemical Parasitology 175:201-204. doi: 10.1016/j.molbiopara. 2010.11.004.

Shaw A. 2004. The economics of African Trypanosomiasis. In: Maudlin I, Holmes P, Miles M, editors. The Trypanosomiases: CABI. p. 369-402. 
Steverding D, Stierhof YD, Chaudhri M, Ligtenberg M, Schell D, Beck-Sickinger AG, Overath P. 1994. ESAG 6 and 7 products of Trypanosoma brucei form a transferrin binding protein complex. European Journal of Cell Biology 64:78-87.

Symula RE, Beadell JS, Sistrom M, Agbebakun K, Balmer O, Gibson W, Aksoy S, Caccone A. 2012. Trypanosoma brucei gambiense group 1 is distinguished by a unique amino acid substitution in the $\mathrm{HpHb}$ receptor implicated in human serum resistance. PLOS Neglected Tropical Diseases 6:e1728. doi: 10.1371/journal.pntd.0001728.

Uzureau P, Uzureau S, Lecordier L, Fontaine F, Tebabi P, Homblé F, Grélard A, Zhendre V, Nolan DP, Lins L, Crowet JM, Pays A, Felu C, Poelvoorde P, Vanhollebeke B, Moestrup SK, Lyngsø J, Pedersen JS, Mottram JC, Dufourc EJ, Pérez-Morga D, Pays E. 2013. Mechanism of Trypanosoma brucei gambiense resistance to human serum. Nature 501:430-434. doi: 10.1038/nature12516.

Vanhamme L, Paturiaux-Hanocq F, Poelvoorde P, Nolan DP, Lins L, Van Den Abbeele J, Pays A, Tebabi P, Van Xong H, Jacquet A, Moguilevsky N, Dieu M, Kane JP, De Baetselier P, Brasseur R, Pays E. 2003. Apolipoprotein L-I is the trypanosome lytic factor of human serum. Nature 422:83-87. doi: 10.1038/ nature01461.

Vanhollebeke B, De Muylder G, Nielsen MJ, Pays A, Tebabi P, Dieu M, Raes M, Moestrup SK, Pays E. 2008. A haptoglobin-hemoglobin receptor conveys innate immunity to Trypanosoma brucei in humans. Science 320:677-681. doi: 10.1126/science.1156296.

Widener J, Nielsen MJ, Shiflett A, Moestrup SK, Hajduk S. 2007. Hemoglobin is a co-factor of human trypanosome lytic factor. PLOS Pathogens 3:1250-1261. doi: 10.1371/journal.ppat.0030129.

Winn MD, Ballard CC, Cowtan KD, Dodson EJ, Emsley P, Evans PR, Keegan RM, Krissinel EB, Leslie AGW, McCoy A, McNicholas SJ, Murshudov GN, Pannu NS, Potterton EA, Powell HR, Read RJ, Vagin A, Wilsonc KS. 2011. Overview of the CCP4 suite and current developments. Acta Crystallographica. Section D, Biological Crystallography 67:235-242. doi: 10.1107/S0907444910045749. 